\title{
Effect of Atmospheric Transmittance on Performance of Adaptive SPD-vacuum Switchable Glazing
}

Aritra Ghosh

University of Exeter

Brian Norton

Technological University Dublin, brian.norton@tudublin.ie

Aidan Duffy

Technological University Dublin, aidan.duffy@tudublin.ie

Follow this and additional works at: https://arrow.tudublin.ie/dubenart

Part of the Engineering Science and Materials Commons

\section{Recommended Citation}

Ghost, A., Norton, B. \& Duffy, A. (2017). Effect of atmospheric transmittance on performance of adaptive SPD-vacuum switchable glazing. Solar Energy Materials and Solar Cells, vol. 161, pg. 424-431.

doi:10.1016/j.solmat.2016.12.022

This Article is brought to you for free and open access by the Dublin Energy Lab at ARROW@TU Dublin. It has been accepted for inclusion in Articles by an authorized administrator of ARROW@TU Dublin. For more information, please contact arrow.admin@tudublin.ie, aisling.coyne@tudublin.ie,gerard.connolly@tudublin.ie.

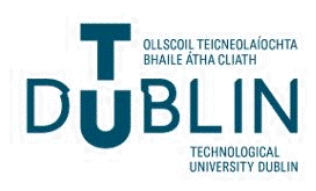




\section{Effect of atmospheric transmittance on performance of adaptive SPD-vacuum switchable glazing}

\section{Aritra Ghosh}

aritra.ghosh@mydit.ie

aritraghosh_9@yahoo.co.in

Brian Norton

Aidan Duffy

Dublin Energy Lab, Dublin Institute of FechnologyTechnology, DublinDublin, Ireland

${ }^{*}$ Corresponding author.

Abstract

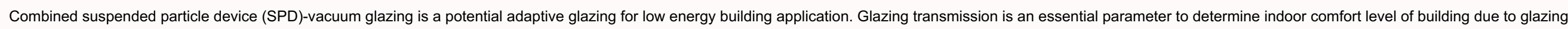

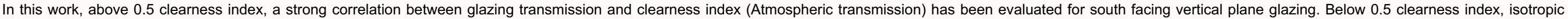

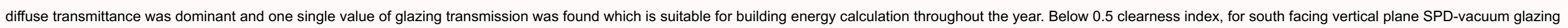
transmission was $17 \%$ and $1.1 \%$ for transparent and opaque states respectively.

Keywords: Adaptive; glazingGlazing; elearnessclearness index;

\section{Nomenclature}

A

Anisotropy index

$I_{\text {beam, }, \mathrm{H}}$

Horizontal plane beam solar radiation $\left(\mathrm{W} / \mathrm{m}^{2}\right)$

$I_{\text {dif, }}$

Horizontal plane beam solar radiation $\left(\mathrm{W} / \mathrm{m}^{2}\right)$

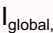

Horizontal plane global solar radiation $\left(\mathrm{W} / \mathrm{m}^{2}\right)$

$\mathrm{I}_{\text {global, }}$

Vertical plane global solar radiation $\left(\mathrm{W} / \mathrm{m}^{2}\right)$

$I_{\text {extra }}$

Extra-terrestrial solar radiation $\left(\mathrm{W} / \mathrm{m}^{2}\right)$ 
Diffuse factor

$\mathrm{k}_{\mathrm{T}}$

Clearness index

$\mathrm{n}_{\mathrm{g}}$

Refractive index of SPD glazing

\section{$\mathrm{N}_{\mathrm{g}}$}

Number of glass pane

SHGC

Solar heat gain coefficient

SE

Transmitted solar energy $(\mathrm{W} / \mathrm{m} / \mathrm{m})\left(\mathrm{W} / \mathrm{m}^{2}\right)$

\section{Greek symbols}

$\alpha_{g}$

Absorptance

T

Transmittance

$\mathrm{T}_{\mathrm{v}}$

Vertical global transmittance

$T_{\text {dir }}$

Direct transmittance

$T_{\text {diff }}$

Diffuse transmittance

$\theta$

Incident angle

$\beta$

Slope angle

\section{Introduction}

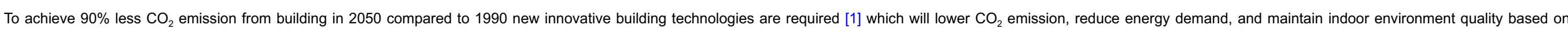

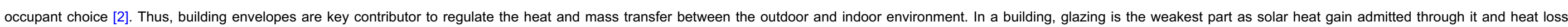




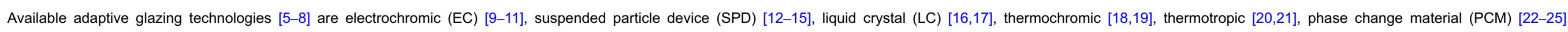
gasochromic [26,27], aerogel [28,29], and vacuum [30]. These glazing are classified in two groups-

- solar heat gain control glazing which change its transparency by electrical (EC,SPD,LC), heat (thermotorpic, PCM) or chemical (gasochromic, thermochromic) actuation;

- low heat loss glazing (aerogel, vacuum, low e coating) which has constant transparency and due to presence of vacuum or insulating material, heat loss through glazing is low.

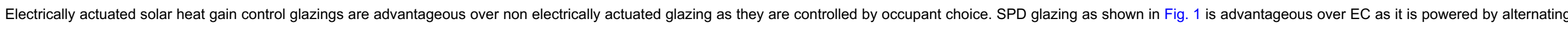

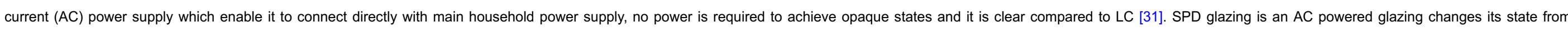

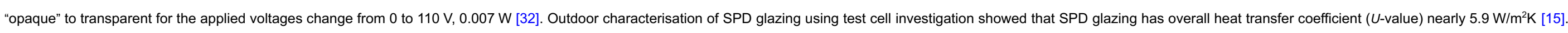

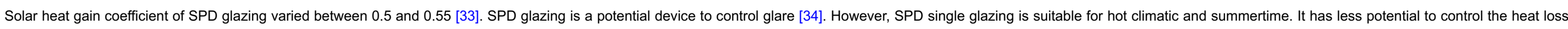
from room to ambient due to its high $U$-value [33].
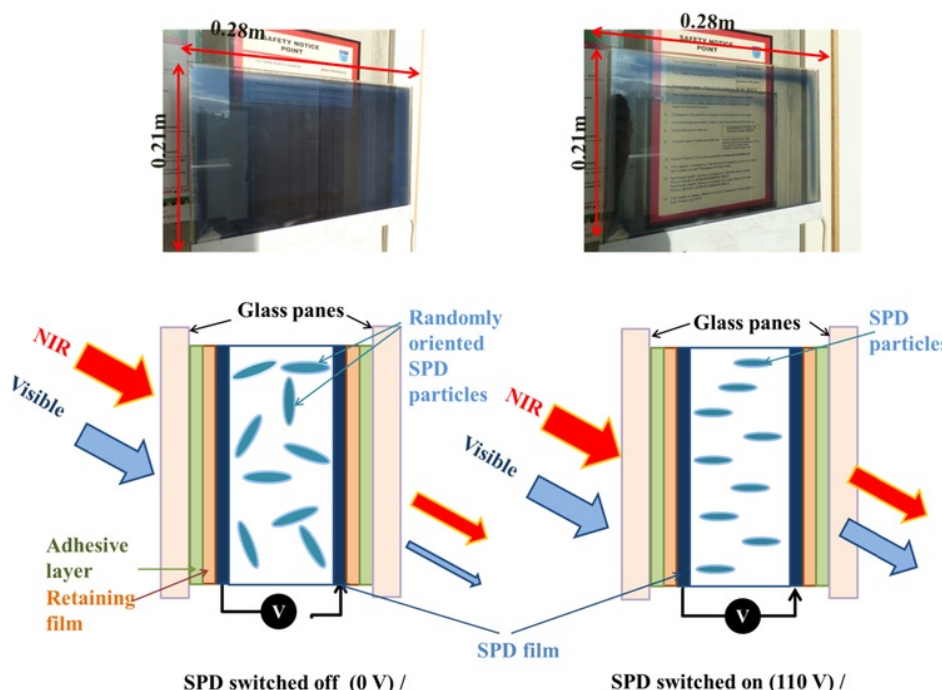

SPD switched off $(\mathbf{0 V}) /$
Opaque" state ( $5 \%$ transparent $)$

"55\% Transparent" state

Fig. 1 Schematic details of suspended particle device switchable glazing "opaque" and "transparent" state.

alt-text: Fig. 1:

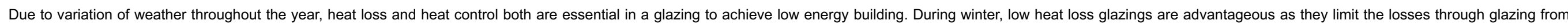

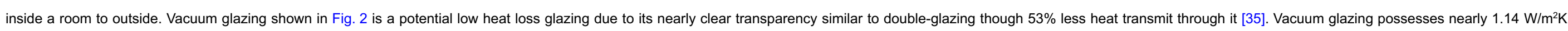

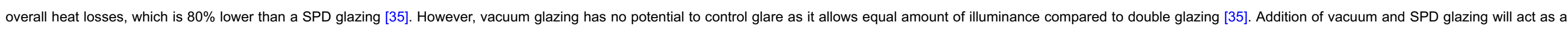
switchable vacuum glazing or low heat loss SPD glazing as shown in Fig. 3. This glazing has solar heat gain control and heat loss control potential as reported by Ghosh et.al. [36]. 


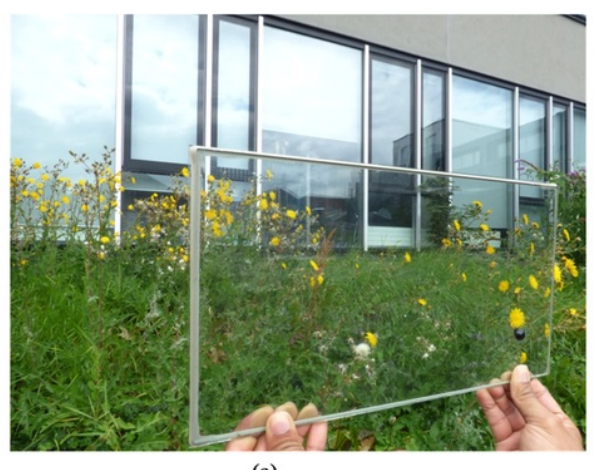

(a)

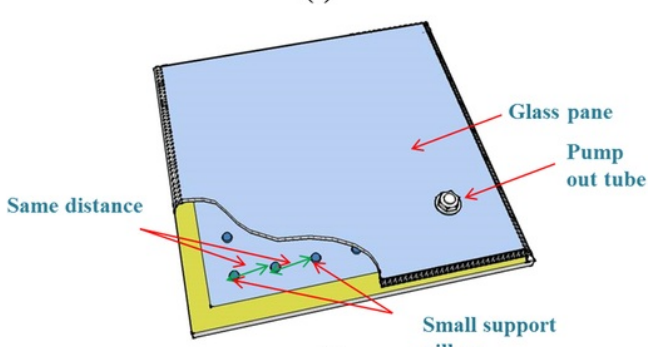

Fig. 2 (a) alt-text: Fig. 2 

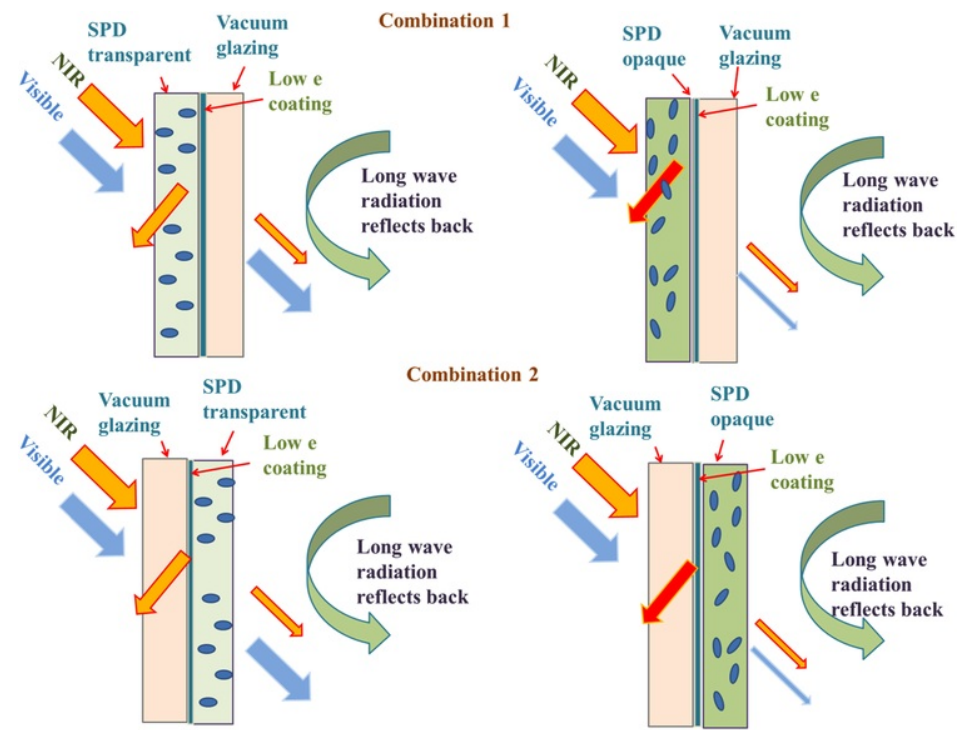

SPD vacuum
$110 \mathrm{~V}, 38 \%$ transparent

SPD vacuum

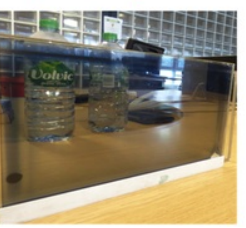

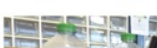

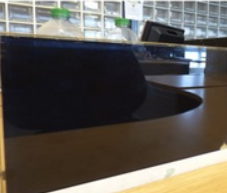

Fig. 3 Detail of a combined SPD-vacuum glazing in its opaque and transparent states.

\section{alt-text: Fig. 3:}

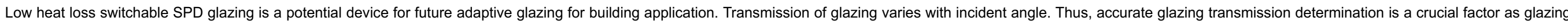

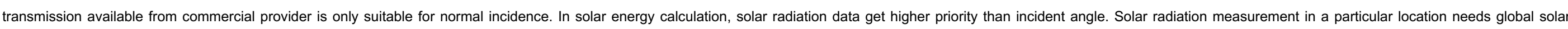

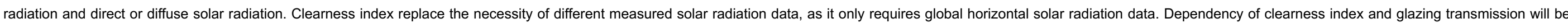

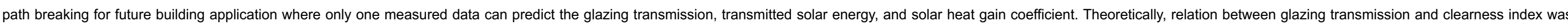

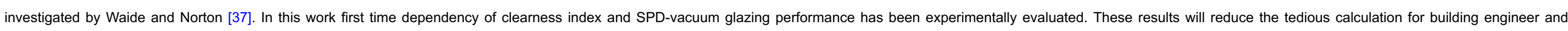
architecture.

\section{Methodology}

For vertical plane SPD-vacuum glazing, angular transmittance $\tau_{v}$ (global solar transmittance through glazing) can be written as $[33,35,36] \mathrm{Eq}$. (1)

$\tau_{v}=\left[k_{d}\left\{k_{T} R_{b}\left(1-k_{d}\right)+(1-\cos \beta)\left(1-k_{T}\left(1-k_{d}\right)\right)\right\}+R_{b}\left(1-k_{d}\right)+R_{g} \frac{1-\cos \beta}{2}\right] \times$

$\tau_{d i r} R_{b}\left(1-k_{d}\right)\left(1+k_{d} k_{T}\right)+\frac{\tau_{d i f} k_{d}}{2}(1+\cos \beta)\left(1-k_{T}\left(1-k_{d}\right)\right)+\frac{\tau_{g} R_{g}(1-\cos \beta)}{2}$ 
$\tau=\frac{1}{2}\left[\frac{1-\left\{\frac{\sin (\theta-n)}{\sin (\theta+n)}\right\}^{2}}{1+\left(2 n_{g}-1\right)\left\{\frac{\sin (\theta-n)}{\sin (\theta+n)}\right\}}+\frac{1-\left\{\frac{\tan (\theta-n)}{\tan (\theta+n)}\right\}^{2}}{1+\left(2 n_{g}-1\right)\left[\frac{\tan (\theta-n)}{\tan (\theta+n)}\right]^{2}}\right] \times \exp \left(\frac{-k_{g} N_{g} t_{g}}{\cos \theta}\right)$

andand

$\tau=\tau_{\text {dir }}$ when $\theta=\theta_{\text {dir }}$

$\tau=\tau_{\text {dif }}$ when $\theta=\theta_{\text {dif }}=59.68-0.1388 \beta+0.001497 \beta^{2}$ [38]

$\tau=\tau_{g}$ when $\theta=\theta_{g}=90-0.5788 \beta+0.002693 \beta^{2}$ [38]

and diffuse factor $\left(k_{d}\right)$ and clearness index $\left(k_{T}\right)$ can be written as Eqs. (3) and (4) respectively.

$k_{d}=\frac{I_{d i f, h}}{I_{\text {global }, h}}$

$k_{T}=\frac{I_{\text {global }, h}}{I_{\text {extra }}}$

Solar energy (SE) transmitted through SPD-vacuum glazing can be written as Eq. (5)[36]

$S E=\left(I_{\text {beam }, h}+I_{d i f, h} A_{i}\right) \tau_{d i r} R_{b}+I_{d i f, h}\left(1+A_{i}\right) \tau_{d i f} \frac{(1+\cos \beta)}{2}$
$+I_{\text {global }, h} \rho_{g} \tau_{g} \frac{(1-\cos \beta)}{2}$

Wherewhere anisotropic index $A_{i}$ can be written by Eq. (6)

$A_{i}=\frac{I_{\text {beam }, h}}{I_{\text {extra }}}$

$I_{\text {extra }}=I_{s c}\left(1+0.033 \cos \frac{360 n}{365}\right)(\cos \phi \cos \delta \cos \omega+\sin \phi \sin \delta)$

$I_{s c}$ is the solar constant, $\mathrm{n}$ is the day of year, $\phi$ latitude angle, $\delta$ declination angle $\omega$ hour angleangle.

Dynamic solar heat gain coefficients (SHGC) can be evaluated by Eq. (8)[36]

$$
S H G C=\frac{S E}{I_{g l o b a l, v}}
$$

\section{Experiment}

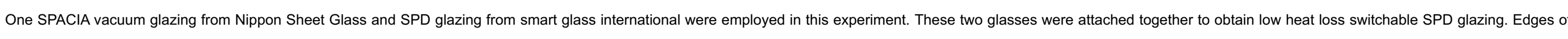

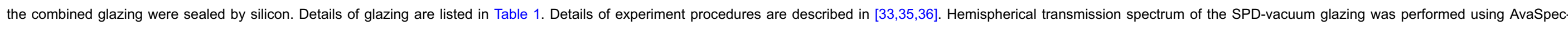

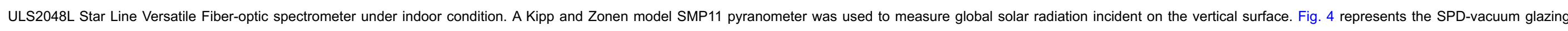
normal hemispherical transmission spectra for transparent and opaque state. After $800 \mathrm{~nm}$ the transmitted infra radiation is higher compare to visible wavelength.

\section{Table 1 Details of glazings. \\ alt-text: Table 1:}

SPD transparent (switch on)+vacuum

SPD opaque (switch off)+vacuum
Solar transmission $(278-1100 \mathrm{~nm})$ 39
Visible transmission $(380-780 \mathrm{~nm})$ 38
Power

$110 \mathrm{~V}, 0.007 \mathrm{~W}$

$0 \mathrm{~V}$

Supplier

Smart glass international (Dublin, Ireland), NSG SPACIA (UK) 


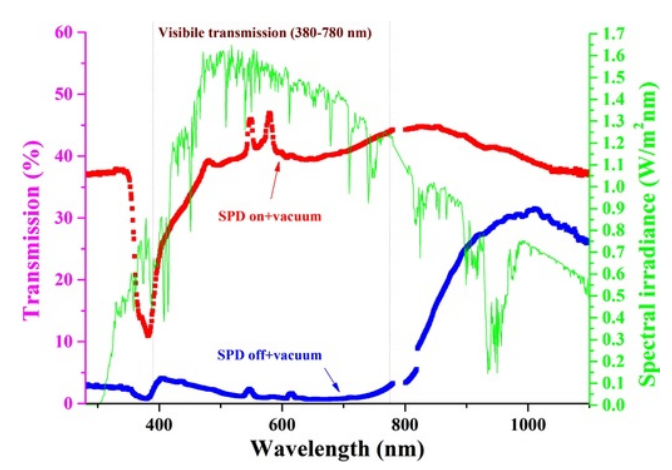

Fig. 4 Transmission spectra of SPD glazing "opaque" and "transparent" states.

\section{alt-text: Fig. 4}

\section{Results \& discussion}

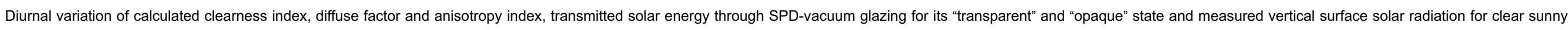

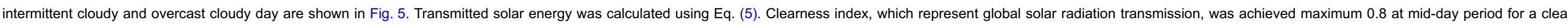

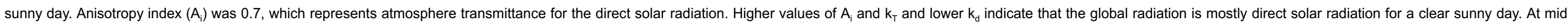

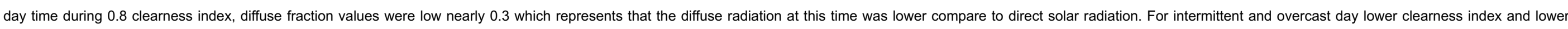

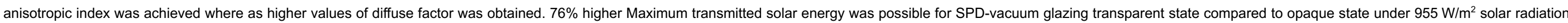
in a typical clear sunny day.

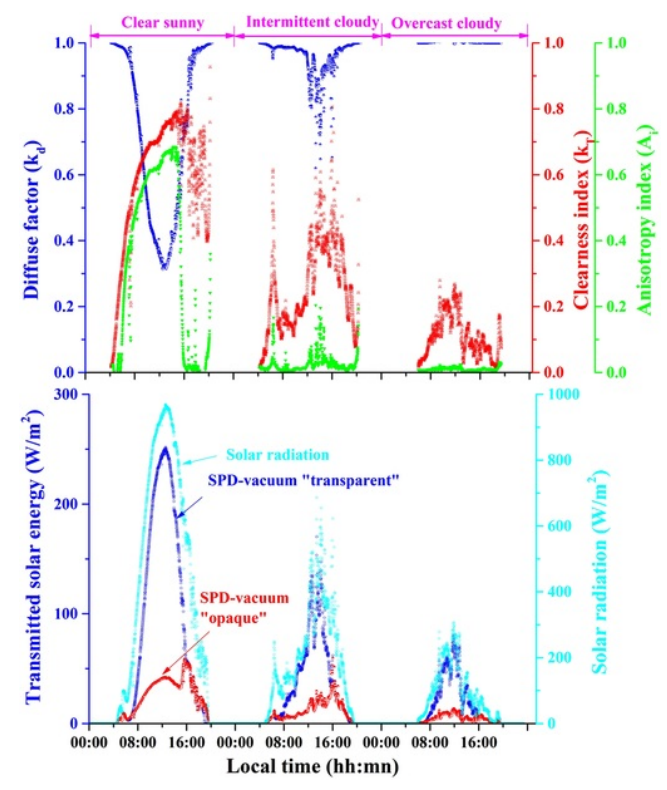

Fig. 5 Diurnal variation of calculated clear ness index, diffuse fraction, anisotropy index, and transmitted solar energy through SPD-vacuum glazing and measured vertical surface solar radiation for clear sunny, intermittent cloudy and overcast cloudy day. alt-text: Fig. 5: 


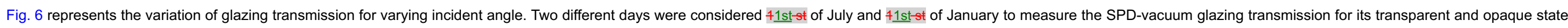
In Dublin location, for south facing vertical plane glazing it is evident that the incident angle varies between $13^{\circ}$ to 82 and $82^{\circ} .-0$ In January, glazing transmission is higher compared to transmission in July.

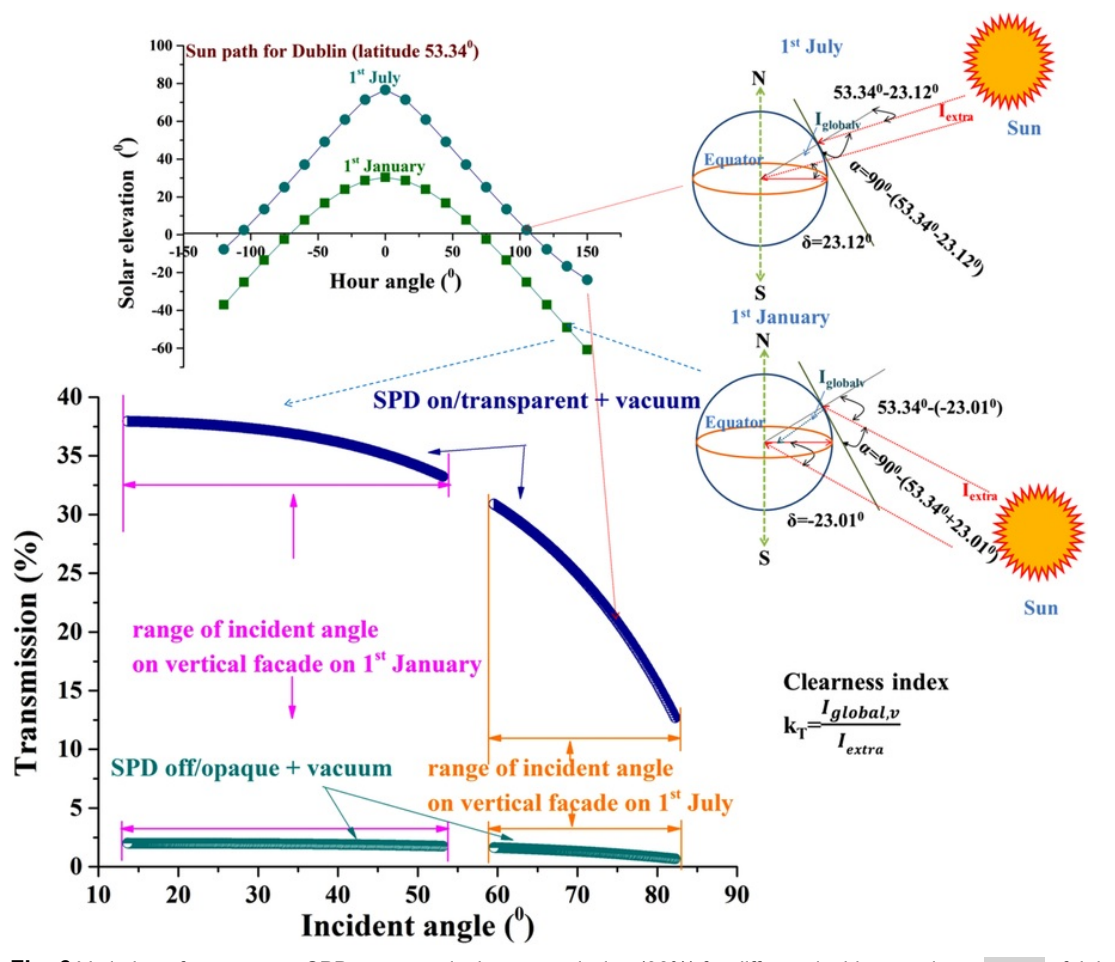

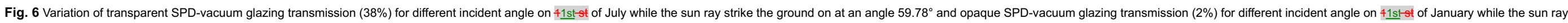
strike the ground on at an angle $13.65^{\circ}$ in Dublin. alt-text: Fig. 6

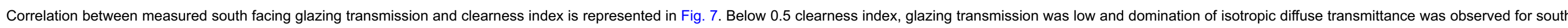

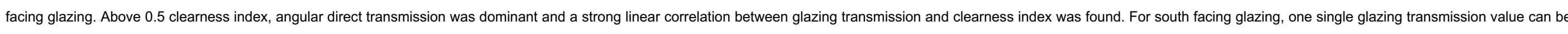

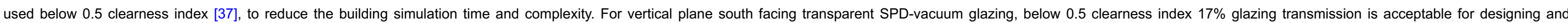

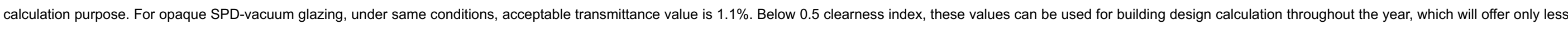
than $1 \%$ error. This glazing transmission is applicable for other azimuthal directions though the threshold values of clearness index changes. Table 2 listed the different clearness index for different azimuthal directions. 


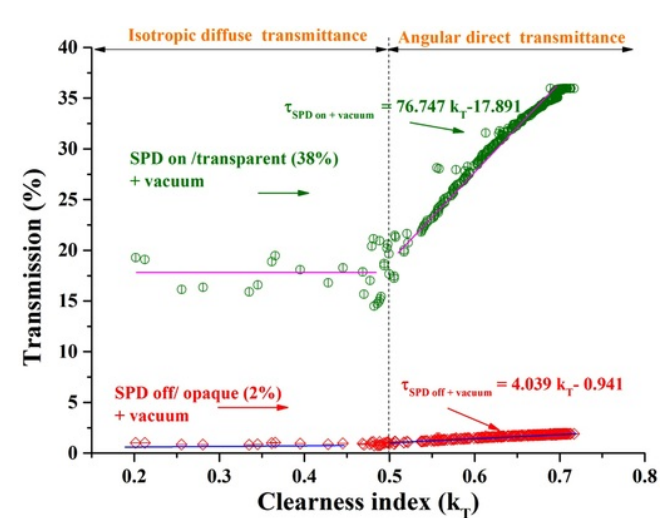

Fig. 7 Variation of south facing combined SPD-vacuum glazing transmission for its opaque and transparent state with clearness index.

\section{alt-text: Fig. 7}

Table 2 Yearly usable single glazing transmission value for SPD-vacuum transparent and opaque state.

alt-text: Table 2:

\begin{tabular}{|c|c|c|c|c|}
\hline & Azimuthal direction & SPD on/transparent+vacuum (38\% transparent) transmission & SPD off/opaque+vacuum ( $2 \%$ transparent) transmission & Mean monthly clearness index \\
\hline & North & 17 & 1.1 & 0.7 \\
\hline & South & 17 & 1.1 & 0.5 \\
\hline \multirow[t]{4}{*}{ Vertical plane SPD-vacuum glazing } & East & 17 & 1.1 & 0.6 \\
\hline & West & 17 & 1.1 & 0.6 \\
\hline & North east & 17 & 1.1 & 0.6 \\
\hline & North west & 17 & 1.1 & 0.6 \\
\hline
\end{tabular}

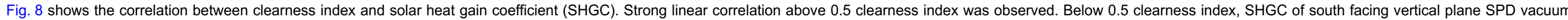

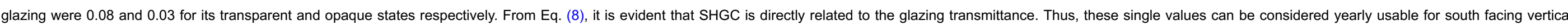

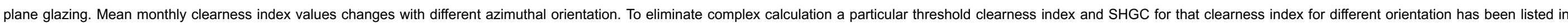
Table 3. 


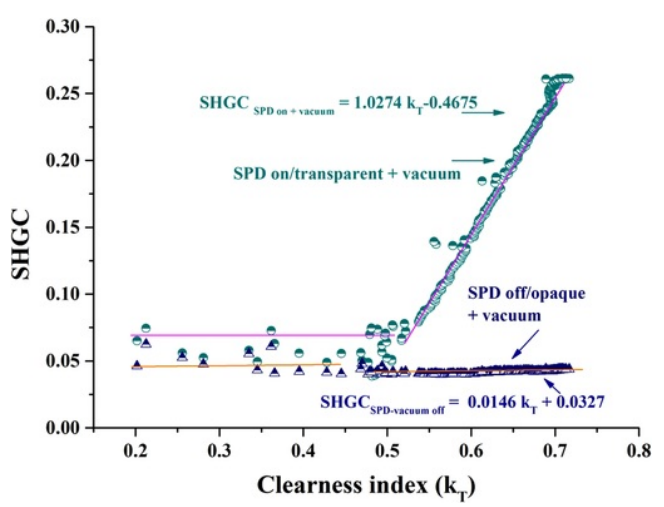

Fig. 8 Variation of solar heat gain coefficient with clearness index.

alt-text: Fig. 8:

Table 3 Yearly usable single SHGC value for SPD-vacuum transparent and opaque state.

alt-text: Table 3

\begin{tabular}{|c|c|c|c|c|}
\hline & Azimuthal direction & SPD on (38\% transparent)+vacuum SHGC & SPD off ( $2 \%$ transparent)+vacuum SHGC & Mean monthly clearness index \\
\hline & North & 0.08 & 0.03 & 0.7 \\
\hline & South & 0.08 & 0.03 & 0.5 \\
\hline \multirow[t]{4}{*}{ Vertical plane SPD-vacuum glazing } & East & 0.08 & 0.03 & 0.6 \\
\hline & West & 0.08 & 0.03 & 0.6 \\
\hline & North east & 0.08 & 0.03 & 0.6 \\
\hline & North west & 0.08 & 0.03 & 0.6 \\
\hline
\end{tabular}

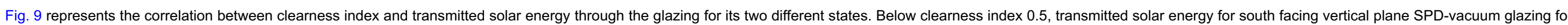

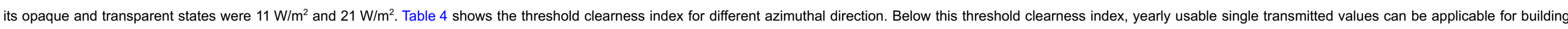

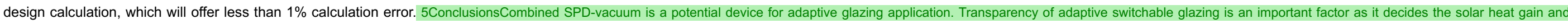

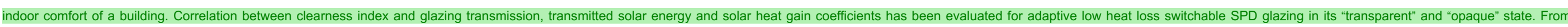

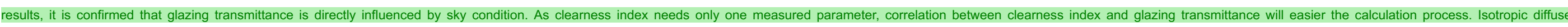

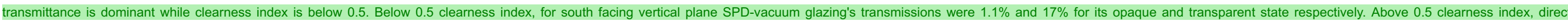

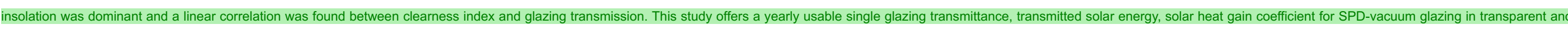

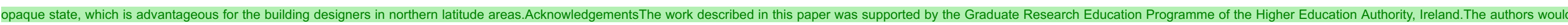
also like to thank the anonymous reviewers for their constructive comments that helped to improve the manuscript. (Please seperate the conclusion and acknowledgement section. Here they are mixe ed which is not acceptable) 


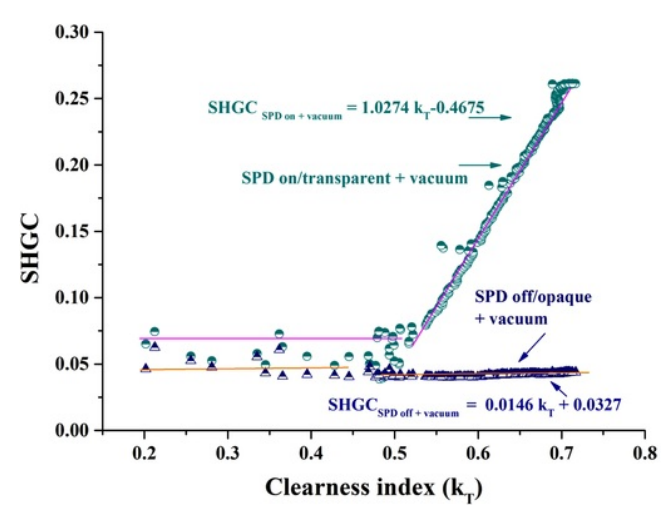

Fig. 9 Dependency of transmitted solar energy through SPD glazing on and off condition with clearness index.

alt-text: Fig. 9: (Please use the attached figure for Figure 9 for clarity)

Table 4 Yearly usable single transmitted energy value for SPD-vacuum transparent and opaque state.

alt-text: Table 4:

\begin{tabular}{|c|c|c|c|c|}
\hline & Azimuthal direction & SPD on ( $38 \%$ transparent)+vacuum transmitted solar energy $\left(\mathrm{W} / \mathrm{m}^{2}\right)$ & SPD off ( $2 \%$ transparent)+vacuum transmitted solar energy $\left(\mathrm{W} / \mathrm{m}^{2}\right)$ & Clearness index \\
\hline & North & 21 & 11 & 0.7 \\
\hline & South & 21 & 11 & 0.5 \\
\hline \multirow[t]{4}{*}{ Vertical plane SPD-vacuum glazing } & East & 21 & 11 & 0.6 \\
\hline & West & 21 & 11 & 0.6 \\
\hline & North east & 21 & 11 & 0.6 \\
\hline & North west & 21 & 11 & 0.6 \\
\hline
\end{tabular}

\section{Acknowledgements}

The authors would also like to thank the anonymous reviewers for their constructive comments that helped to improve the manuscript.

The work described in this paper was supported by the Graduate Research Education Programme of the Higher Education Authority, Ireland.

\section{References(Please keep the section $\mathbf{5}$ conclusion and acknowledgements will come after conclusion section)}

[1] Roadmap 2050 Volume 1: Technical and EconomicAnalysis, accessed online in May 2016 at/http://www.roadmap2050.eu/attachments/files/Volume1_ExecutiveSummary.pdf〉

[2] Energy Performance of Buildings Directive recast2010/31/EU (2010):2010._-areas/buildings/EPBD_Recast/EPBD_recast_19May2010.pdf>>>>.

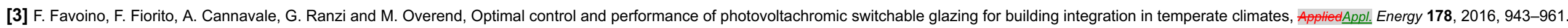

[4] F. Favoino, M. Overen and Q. Jin, The optimal thermo-optical properties and energy saving potential of adaptive glazing technologies, AppliedAppl. Energy 156, 2015, 1-15.

[5] A. Seeboth, J. Schneider and A. Patzak, Materials for intelligent sun protecting glazing, Sotarsol. Energy

[6] G. Gorgolis and D. Karamanis, Solar energy materials for glazing technologies, Solar.Sol. Energy Haterials and Solar Mater. Sol. Cells 144, 2016, 559-578.

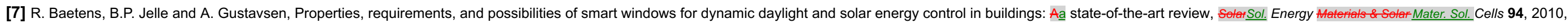




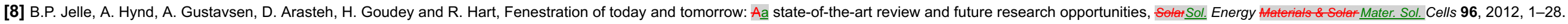

[9] C.M. Lampert, Towards large-area photovoltaic nanocells: experiences learned from smart window technology, Solar Soll. Energy Hateriat \& Solar cetts Mater. Sol. Cells 11, $1984,1-27$.

[10] C.M. Lampert, Smart switchable glazing for solar energy and daylight control, solarSol. Energy Ahaterials \& Solar Mater. Sol. Cells 52, 1998, $207-221$.

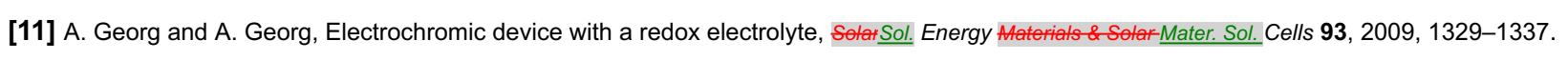

[12] R. Vergaz, J.M.S.N. Pena, D. Barrios, C. Va'zquez and P.C. Lallana, Modelling and electro-optical testing of suspended particle devices, StatSol. Energy Aateriats \& Sotar Mater. Sol. Cells 92, $2008,1483-1487$.

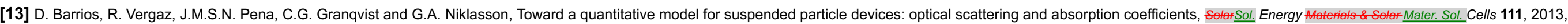
$115-122$.

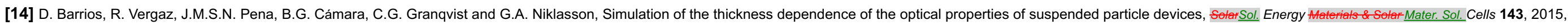
613-622.

[15] A. Ghosh, B. Norton and A. Duffy, Measured overall heat transfer coefficient of a suspended particle device switchable glazing, AppliedAppl. Energy 159, 2015, 362-369.

[16] D.J. Gardiner, S.M. Morris and H.J. Coles, High-efficiency multistable switchable glazing using smectic A liquid crystals, SolarSOl. Energy Araterials \& Soltar-Mater. Sol. Cells 93, 2009, 301-306.

[17] C.M. Lampert, Chromogenic smart materials, AtateriatsMater. Today 7, 2004, 28-35.

[18] V. Costanzo, G. Evola and L. Marletta, Thermal and visual performance of real and theoretical thermochromic glazing solutions for office buildings, Soltar Sol. Energy Hateriats and Sotar Mater. Sol. Cells 149, 2016, 110-120.

[19] M.E.A. Warwick, I. Ridley and R. Binions, The effect of variation in the transition hysteresis width and gradient in thermochromic glazing systems, SolarSol. Energy Alaterials and Solar-Mater. Sol. Cells 140, $2015,253-265$.

[20] P. Nitz and H. Hartwig, Solar control with thermotropic layers, SolarSol. Energy 79, 2005, 573-582.

[21] A. Weber and K. Resch, Thermotropic glazings for overheating protection, Energy Procedia 30, 2012, 471-477.

[22] F. Goia, Thermo-physical behaviour and energy performance assessment of PCM glazing system configurations: Aa numerical analysis, Frentiers of ArehiteeturalResearehFront. Archit. Res. 1, $2012,341-347$.

[23] F. Goia, M. Zinzi, E. Carnielo and V. Serra, Spectral and angular solar properties of a PCM-filled double glazing unit, Energy

[24] F. Goia, M. Perino and V. Serra, Experimental analysis of the energy performance of a full-scale PCM glazing prototype, Solar Sol. Energy 100, 2014, 217-233.

[25] F. Goia, M. Perino and V. Serra, Improving thermal comfort conditions by means of PCM glazing systems, Energy and BuillingsBuild. 60, 2013, 442-452.

[26] A. Georg, W. Graf, R. Neumann and V. Wittwer, Stability of gasochromic $\mathrm{WO}_{3}$ films, Sotar Sol. Energy Atateriats \& Solar Mater. Sol. Cells 63, 2000, 165-176.

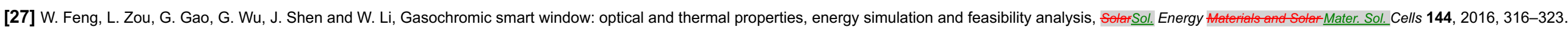

[28] C. Buratti and E. Moretti, Experimental performance evaluation of aerogel glazing systems, AppliedAppl. Energy 97, 2012, 430-437.

[29] J.M. Schultz, K.I. Jensen and F.H. Kristiansen, Super insulating aerogel glazing, SolarSol. Energy

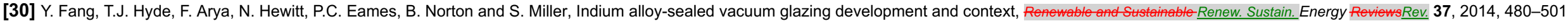

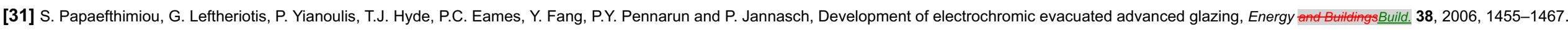

[32] A. Ghosh, B. Norton and A. Duffy, First outdoor characterisation of a PV powered suspended particle device switchable glazing, Sotar Sol. Energy \#tateriats \& Sotar Mater. Sol. Cells 157, 2016, 1-9. 
[33] A. Ghosh, B. Norton and A. Duffy, Behaviour of a SPD switchable glazing in an outdoor test cell with heat removal under varying weather conditions, AppliedAppl. Energy 180, 2016, 695-706.

[34] A. Ghosh, B. Norton and A. Duffy, Daylighting performance and glare calculation of a suspended particle device switchable glazing, solar Sol. Energy 132, 2016, 114-128.

[35] A. Ghosh, B. Norton and A. Duffy, Measured thermal \& daylight performance of an evacuated glazing using an outdoor test cell, AppliedAppl. Energy 177, 2016, 196-203.

[36] A. Ghosh, B. Norton and A. Duffy, Measured thermal performance of a combined suspended particle switchable device evacuated glazing, AppliedAppl. Energy 169, $2016,469-480$.

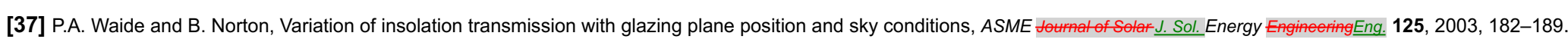

[38] M.J. Brandemuehl and W.A. Beckman, Transmission of diffuse radiation through CPC and flat-plate collector glazings, SolarSOl. Energy 24, 1980, 511-513.

Highlights

- Correlation of SPD-vacuum glazing transmittance and clearness index has been calculated.

- Transmitted solar energy and SHGC was evaluated for different clearness index.

- Single glazing transmittance value was recommended below 0.5 clearness index.

- Maximum transmitted SE was $76 \%$ higher in SPD-vacuum transparent state than opaque.

\section{Queries and Answers}

Query:

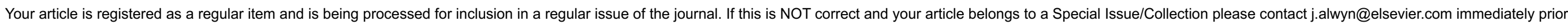
to returning your corrections.

Answer: It is a regular item 